\title{
Popular 'superstition' undermining piety amongst Christians: A case study of Mutemwa pilgrimages in Zimbabwe
}

\begin{tabular}{|c|c|}
\hline \multicolumn{2}{|c|}{$\begin{array}{l}\text { Authors: } \\
\text { Sekgothe Mokgoatšana }{ }^{1} \\
\text { Mischeck Mudyiwa }^{1,2} \\
\text { Tabona Shoko }^{1,2}\end{array}$} \\
\hline \multicolumn{2}{|c|}{$\begin{array}{l}\text { Affiliations: } \\
{ }^{1} \text { Department of Cultural } \\
\text { and Political Studies, } \\
\text { Faculty of Humanities, } \\
\text { University of Limpopo, } \\
\text { Sovenga, South Africa }\end{array}$} \\
\hline \multicolumn{2}{|c|}{$\begin{array}{l}\text { ²Department of Religious } \\
\text { Studies, Classics, and } \\
\text { Philosophy, University } \\
\text { of Zimbabwe, Harare, } \\
\text { Zimbabwe }\end{array}$} \\
\hline \multicolumn{2}{|c|}{$\begin{array}{l}\text { Corresponding author: } \\
\text { Sekgothe Mokgoatšana, } \\
\text { sekgothe@gmail.com }\end{array}$} \\
\hline \multicolumn{2}{|c|}{$\begin{array}{l}\text { Dates: } \\
\text { Received: } 12 \text { May } 2020 \\
\text { Accepted: } 29 \text { July } 2020 \\
\text { Published: } 25 \text { Nov. } 2020\end{array}$} \\
\hline \multicolumn{2}{|c|}{$\begin{array}{l}\text { How to cite this article: } \\
\text { Mokgoatšana, S., Mudyiwa, } \\
\text { M. \& Shoko, T., 2020, } \\
\text { 'Popular "superstition" } \\
\text { undermining piety amongst } \\
\text { Christians: A case study of } \\
\text { Mutemwa pilgrimages in } \\
\text { Zimbabwe', HTS Teologiese } \\
\text { Studies/Theological Studies } \\
\text { 76(4), a6117. https://doi. } \\
\text { org/10.4102/hts.v76i4.6117 }\end{array}$} \\
\hline \multicolumn{2}{|c|}{$\begin{array}{l}\text { Copyright: } \\
\text { (c) 2020. The Authors. } \\
\text { Licensee: AOSIS. This work } \\
\text { is licensed under the } \\
\text { Creative Commons } \\
\text { Attribution License. }\end{array}$} \\
\hline \multicolumn{2}{|l|}{ Read online: } \\
\hline 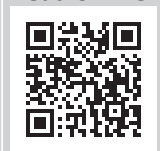 & $\begin{array}{l}\text { Scan this QR } \\
\text { code with your } \\
\text { smart phone or } \\
\text { mobile device } \\
\text { to read online. }\end{array}$ \\
\hline
\end{tabular}

Prayers and places of worship are perhaps as old as humanity. A comprehensive survey of the dynamics and dialectics of African Christianity, Zimbabwe in particular, reveals that pilgrimages to holy places are a popular and common phenomenon. Of the many sacred places dotted around the Zimbabwean Christian landscape, Mutemwa shrine, located close to Mutoko Business Centre, is perhaps the most visited and popular, attracting thousands of Christians (particularly Catholics) from all the 10 provinces of Zimbabwe. Inseparably connected with the life and charity works amongst lepers by John Randal Bradburne (1921-1979), the shrine has been referred to as a case of popular, celebrated and fashionable religiosity by many pilgrims. This article explores the phenomenon of popular 'superstition' associated with Mutemwa pilgrimages with a view to assess and examine the orthodoxy, impact and implications of this popular devotion. The main argument developed in this article is that whilst innumerable pilgrims confess that pilgrimages to Mutemwa shrine provide imminent answers and solutions to their day-to-day problems, to some extent, popular 'superstition' associated with Mutemwa shrine has undermined the degree of piety amongst Zimbabwe's Christian populace. As the article probes deeper, parallel practices within the African (particularly Shona) traditional religion and spirituality, Old and New Testaments as well as the tried and tested tradition of the Christian Church shall also be explored and critically examined.

Contribution: This article contributes to the ongoing debates on shrines as fetish and sacred spaces of 'worship' and reconnoitre, (re)appropriating pilgrimage as religious discourse, memory and the fulcrum of religious tourism. Pilgrimages to African shrines will also help us understand religious syncretism in Africa and the world over.

Keywords: popular superstition; piety; Mutemwa pilgrimages; John Bradburne; African Christianity.

\section{Introduction}

Whilst the contribution of Catholic expatriate missionaries during the war of liberation in Zimbabwe may not be overstated (McLaughlin 1996), the orthodoxy of Mutemwa pilgrimages ${ }^{1}$ and the various factors that give anchorage to Mutemwa as an increasingly popular shrine in Zimbabwe require particular attention. Ever since the demise of John Randall Bradburne, a lay member of the Order of St Francis, a poet, warden of the Mutemwa leper colony at Mutoko, in 1979, statistics indicate that year in and year out, thousands of Catholics and Christians from other traditions (mostly women) flock to Mutemwa shrine, particularly in September, which marks the death anniversary ('martyrdom') of John Randal Bradburne whom they regard as a saintly figure (Murape 2012:viii). In order to fully account for factors associated with the Mutemwa pilgrimage phenomenon, the article used both primary and secondary sources of data collection in order to gain understanding and insight into the nature and character of Mutemwa pilgrimages. Thus, interviews, participant ${ }^{2}$ observation and documentary analysis were crucial as data gathering tools. Literature review on The concept 'pilgrimage' is a multilayered and/or faceted concept, which includes ideas of a journey to a sacred and holy place, experiencing exile, living as a pilgrim or sojourn and the quest for a homeland. Thus the 11th Chapter of the letter to the Hebrews underlines, amongst other things that the Patriarchs such as Abel, Enoch, Noah, Abraham and Jacob were strangers and pilgrims on earth. For purposes of this article, the word 'pilgrimage' is used in reference to a journey that a religious person makes to a holy and sacred place. Whilst pilgrimages are also a common phenomenon amongst pagan religions, the interest in this article is Christian, particularly, Catholic pilgrimages.

2.As a result of the sensitivity and potentially divisive nature of the topic, a handful of interviewees, however, preferred anonymity And for that reason, participants who requested for anonymity have not been divulged. Authors have thus used pseudo names instead of their real names.

Note: Special Collection entitled Social Memory Studies, sub-edited by Christina Landman (UNISA) and Sekgothe Mokgoatšana (UL). 
John Bradburne that is available in libraries and online contributed significantly in giving this article both a theoretical and narrative orientation. These include Dove (1990), Murape (2012), Rogers (2017), Rance (2018), Tomei (2018) and Karombo (2019), amongst many others.

To accommodate individual variation, the authors used both structured and semi-structured interviews. Whilst most interviews were directed at consistent Mutemwa pilgrims, some questions, however, targeted Christians who seemed to hold an unfavourable view with regard to Mutemwa pilgrimages. These were interviewed by the authors in the comfort of their parishes and homes in Harare diocese, which happens to be the resident diocese for the two authors.

It must also be mentioned that one of the authors, on a number of occasions, particularly in the month of September, apparently spent an extensive period of time with pilgrims at Mutemwa shrine. In participant observation, the author actively participated in ongoing activities at Mutemwa such as praying the Rosary, celebration of the Lord's Supper, adoration of the Blessed Sacrament and climbing the nearby Chigona hill, amongst many other activities that are consistent with the Mutemwa pilgrim. In order to explore and account for the alleged 'superstition' associated with such visits, the authors carefully recorded the observations and phenomena as they revealed themselves. Before we give a brief history of Mutemwa shrine and examine the orthodoxy of Mutemwa pilgrimages, it is however, necessary to first provide background information on the nature of the African traditional spirit worldview in order to understand the religious context(s) of African Christians and ascertain the extent to which Mutemwa pilgrims could have been shaped and influenced by their own traditional worldview.

\section{The Shona traditional worldview}

An understanding of the intricacy of the Shona traditional worldview is critical in any discussion about the African culture, shrines, prayers and pilgrimages as it shall prove illuminating in getting at the foundation and basis upon which Mutemwa pilgrimages possibly find their anchorage and pivot.

From an African contextual landscape, the fact that the Shona traditional religion is complex cannot be denied. The belief in spirits, witchcraft and spirit possession is, however, a common phenomenon in Zimbabwe, particularly the antecedent Shona and Ndebele traditional spirit worldviews that largely shaped the various Christians (and nonChristians) that often visit Mutemwa shrine for fortunes. The Shona people, like in many other African traditions understand and interpret their traditional cosmology in religious terms (Shoko 2007:38). They strongly believe in the existence of a spirit world, the abode of a Supreme Being whom they call Mwari, a personal name for God. Mwari is believed to be a personal Being, more powerful than any other spirit (Bourdillon 1976:277). The Shona people refer to him as the Great One who made everything. He is the Great Spirit that stays in the world of spirits (kumatenga).
Whilst Mwari is the commonly used name, God is also known by various other praise names or attributes within the Shona/Ndebele cultures. The great number of names designating the Supreme Being, Creator, Uncaused Cause and Unmoved Mover (Thomas Aquinas) often reveal the nature, function and the association of the Divine with different phenomena of nature. ${ }^{3}$ Some of the names of Mwari include: Nyadenga or Dedza [Lord of the Sky], Musikavanhu (Maker/Creator of people/umdaliwabantu), Chikara [One inspiring awe], Dzivaguru (Great pool/iszibaesikhulu), Samasimba [The all Powerful] and Chirazamauya. The derivation here is Chiraza (from Kuraza-to provide) and Mauya [a good thing or person]. Thus, the name describes God as the one who provides for good and bad (Van der Merwe 1957:8). For the Shona people, Mwari is their final authority, above and behind their ancestors, and can/could only be consulted on matters of national importance.

Although they believe in (Mwari), the Shona people also believe that their lives are controlled by their ancestral spirits (vadzimu), be they paternal or maternal. Vadzimu are the spirits of departed relatives of the surviving members of the family such as fathers, mothers, grandparents, uncles and aunts. These have a dual or twin structure such that the Shona people perceive them as 'half spirits and half humans' (Shoko 2007:33). Mbiti would refer to them as, 'the living dead' (Mbiti 1975:70). Apart from ancestral spirits, there are also several other spirits that populate the Shona spirit worldview. These also include: Clan spirits (Mhondoro), Mashave [alien spirits], Ngozi [avenging spirits], Goblins (zvikwambo), Magoritoto [Ghosts], Zvipoko [Spooks] or familiars (zvidhoma). All the enumerated spirits go to make up the spirit world of the Shona people and are all under the great omnipotent God (Gelfand 1976:132). The same is also confirmed by Shoko (2007:40-43). Such spirits are a powerful $\operatorname{cog}$ in the Shona spiritual world and are capable of causing illnesses such as psychological, physical and psychic disorders, which may need only their spiritual hierarchy such as ancestral spirits or Mwari to intervene and eradicate (Shoko 2006:351).

Gelfand (1976:59) highlights two kinds of bad people, within the Shona society, namely, the witch (muroyi) and the bad person (munhu akaipa). As underscored by Shoko (2007:47), whilst a muroyi is associated with witchcraft, deadly and menacing evil spirits such as zvidhoma, zvitokorochi, zvivanda, zvitupwani, a bad person is associated with jealousy and often does not respect other people's property. He or she is pleased with his or her neighbour's misfortune and misery. For these and many other reasons, these evil spirits are amongst the most feared in the Shona society, especially if there is jealousy and irreconcilable hatred between two or more families. This means that in many cases, 'death, illness and misfortune are

3.Of all the southern and eastern African tribes, the southern Shona have the most elaborate cult for worshipping and consulting the Supreme Being. For centuries they have believed in Mwari as the final authority behind their ancestors, a High God who was perhaps less directly involved in the affairs of individual lives than the ancestors, but one who could be consulted on matters of communal import. Thus, fundamentally, pre-Christian belief in a Supreme Being contributed considerably towards shaping the destiny of the Shona people (Confer, Daneel 1970:15). 
considered the outcome of evil intent of mostly relatives, rather than of natural causes' (Largerwerf 1987:5).

Understandably so, the Zimbabwe Catholic Bishops' Conference (1989:16) underlines that like most Africans, the Shona people thus believe that illness or misfortune is often caused by some evil people with the aid of evil spirits at their command, the cure of which consists of eliminating that harmful spiritual influence or the person through rituals and sometimes pilgrimages for prayers. Thus, the traditional Shona people do not ask the question: what has caused the illness? Rather, they ask: who has caused the illness? For this reason, when the same people (Shona) approach the Gospel, they do so with heightened healing expectations and hopes. They always expect their priests to wrestle with witchcraft, sorcery and spirit possession and with triumphant victory come to grips with the problem of sickness and poverty in their lives, employing some spiritual means to cure and heal their infirmities, to defeat, destroy and dismantle powers and principalities of darkness that always militate against human prosperity and breakthroughs. Given what has been discussed above, it may be convincingly argued that within the Shona traditional religion, prayers and places of prayer, therefore, occupy a pivotal and irreplaceable role.

\section{Shrines, prayers and pilgrimages in the Shona traditional cosmology}

Mbiti (1975) and Gelfand (1976), amongst many other scholars examined the function of shrines, prayers and pilgrimages in the African traditional worldview. The two concur that whilst there are no sacred writings in African religion, rituals, ceremonies and festivals, the same people (Africans) do articulate quite clearly their religion and these are imbued and sopped with religious meaning, value and significance. Whilst some rituals are limited and celebrated at family level, other rituals of greater magnitude and influence are celebrated at community level. To that effect, the rich African religion is not only found in rituals, festivals and ceremonies but also in shrines, sacred places, religious objects and all aspects of life.

As underlined by Mbiti (1975:19), whereas places such as graves, small huts or mounds in the homestead or behind houses may qualify as family shrines, sacred places such as rocks, caves, hills, mountains, trees, rivers, amongst others have often been used as community shrines. These are often natural places turned by human beings into shrines and sanctuaries. At these shrines and sacred places, people make or bring sacrifices and offerings, such as animals, fowls, food, utensils, tools and coins. Because they regard these places with the highest religious esteem, as holy and sacred where they communicate with Mwari/God, they routinely make their prayers and offerings at such sacred places. Such prayers often include: praise, thanksgiving or requests. Requests cover a wide range of areas such as good health, protection from danger, safety in travelling, security, prosperity, preservation of life, peace, rains, good harvest and various other individual and community benefits. Community benefits are often associated with prayer for rain, peace, cessation of epidemics and dangers to the nation, success in wars or raids, acceptance of sacrifices and offerings, and fertility for people, animals and crops (Mbiti 1975:55-56).

As they pray and pour out their souls at such shrines, the Shona believe that they come as close as possible to the hierophany, to God/Mwari who is the provider of all that is good (Chirazamauya). They believe that through prayers they strengthen their bond with their spiritual hierarchy and protectors. To further strengthen that affinity and spiritual bond, prayers always accompany sacrifices and offerings to draw the attention of God or solicit their ancestors to come to their aid and urgently address all their needs. Such ceremonies are often punctuated by music and dance as believers emotionally participate in the proceedings. In most cases, their songs often reveal their intentions, be they joyful, sorrowful or thanksgiving. It is critical to underline the fact that one of the most widely known of such shrines is Matonjeni of the Mwari cult in Matopos (Bulawayo) where the voice of Mwari 'could be heard' from the deep recesses of the cave or later believed to have spoken through mediums (Murape 2012:26). Daneel (1970:15) and Ranger (1999:21) confirm the same strange voices from the same rock in Bulawayo. Such a place and many more of similar religious value and significance would be looked after by people specially selected by the community, particularly ritual and religious leaders. These would ensure the general tidiness of such places 'and see to it that they are kept in order where and when necessary' (Mbiti 1975:146).

For that reason, it is critical to underline that before the advent of missionaries in Zimbabwe, the local people had been deeply religious (Chimhanda 2014). After converting to Christianity, the same people have interpreted the issue of shrines and sanctuaries in Shona traditional religion as a preparation for the Gospel of Christ with its concepts of veneration of saints, shrines, prayers and pilgrimages. Whilst civilisation has to some extent diluted and neutralised some elements of the Shona traditional religion, it has, however, failed to break some of the fundamentals of the indigenous religion, particularly with regard to issues of health and well-being, shrines and pilgrimages. Thus, taking cognisance of the fact that the entire life of the Shona people has largely been founded and anchored mainly on traditional religion and spirituality, a shift or transition to a more or less similar practice, like the one at Mutemwa Leprosy Centre would, therefore, not be regarded as too difficult or alien. Before examining the orthodoxy, impact and implications of Mutemwa pilgrimages, it is essential for the article to focus its attention on the history of pilgrimages at Mutemwa shrine, in Mutoko, about $143 \mathrm{~km}$ from Salisbury (now Harare). The history of Mutemwa pilgrimages is inseparably linked and connected to the life and works of John Bradburne. 


\section{The life and works of John Randal Bradburne}

Dove (1990), Rogers (2017) and Rance (2018) traced the biography of John Bradburne. The life history of John is paramount to the understanding of the factors that make Mutemwa a place of popular religiosity and piety in Zimbabwe. John Bradburne, 'a saintly missionary Englishman' was born on the 14th of June 1921 into a parsonage in Skirwith Cumbria and went to school at Gresham (Rance 2018). Born of Anglican parents, Thomas William and Erica May Bradburne, John was baptised as an Anglican on 31st of July 1921. He had two brothers and two sisters. Philip and Mary were the older. Audrey and Michael came after him (Dove 1990:33).

John had a fair and balanced academic career that was, however, aborted when he eventually joined the Second World War (1939-1945) in the Malayan jungles. After the war, he became restless, compelled by an undying insatiable passion and appetite to travel around the globe, as if to fulfil the famous statement by St Augustine that, 'Our hearts are restless Lord, until they rest in thee' (Dove 1990:34). This seemingly unquenchable and uncontrollable passion made him a perennial religious freelancer and vagabond. Whereas Rance (2018:xiv) referred to John as a man who traipsed round monasteries in Europe in search of his heart's desire, after the Second World War, Dove (1990) referred to him as the strange vagabond of God.

\section{Finding a new home}

Failing to find his heart's desire in the heart of England, in 1962 John finally turned his mind and consideration on the African continent, Zimbabwe in particular. When John Bradburne finally arrived in the then Rhodesia (now Zimbabwe), he was introduced by his Jesuit friends to the already existing but seemingly neglected Mutemwa Leprosy Care Centre near Mutoko in 1969, which he instantly regarded as his 'dream cave'. Dove (1990:211) underlined that Mutemwa in Shona means 'you are cut off', as if to confirm that the place was cut off, isolated and disconnected from the rest of the world. He adds that by the time John was introduced to Mutemwa Leprosy Centre, the place had about a hundred lepers. Before the arrival of John, the centre had been a huge leprosarium with more than a thousand lepers. A good number of them were diseased foreigners, expatriate farm workers from Southern African countries such as Malawi, Mozambique and Zambia. Others were from local tribes as well. However, when John was introduced to his new home, most of the lepers had returned to their villages, whilst other cases had been evacuated elsewhere. The few who had remained were badly deformed or unable to return for one reason or another. These were under the care and custody of the government's Social Welfare Department. The government had assigned an African warden, an ex-policeman and a few orderlies to take good care of the place. Dove (1990:211) emphasised that the lepers were given huts, scant food ration, some clothing and blankets, but the home lacked love.
Dove (1990:viii) further highlighted that by the time John arrived and joined his new community, most roofs of their tin houses were almost caving in. There was an old dilapidated chapel that had been built years before by Bishop Chichester, the first Bishop of the Diocese of Harare. Holy Mass was celebrated in a hall that was away from the camp. Unfortunately, with their condition, lepers could not crawl for long distances in search of such spiritual services. When John arrived, he did not mind the dirty and hungry lepers or the condition of his new home. The whole area of Mutemwa was something dear to him (Murape 2012:xii). Having fallen in love with Mutemwa Leprosy Centre, John promised three things to his Jesuit Rhodesian allies. First, to help the Mutemwa victims of leprosy to the best of his ability. Second, to die as a martyr in Rhodesia. Third, to be buried in the Franciscan vestment or Habit.

For 10 years (1969 to 1979), Bradburne, the new Warden of Mutemwa Leprosy Care Centre became a darling for the lepers, 'many whose very deformed bodies bear [bore] witness to the ravages of the ailment' (Murape 2012:viii). Amongst many other works of charity, he helped construct their own chapel in order to ignite their relationship with God and also organised their music. He gave each leper a name and wrote a poem about each of them (Rance 2018). At the First International Conference on John Bradburne (1921-1979): Poet, Mystic and Martyr held in the Great Hall of the Universita per stranieri di Perugia on 30 March 2017, David Crystal drew attention to John's status as the most prolific poet in the English language (Tomei 2018:x). In addition to writing poems, he cooked for them and fed them. He washed their clothes and bathed them. He looked for them day and night and did not hesitate to bury those who died. Dove (1990:229) underlined that John witnessed many deaths at Mutemwa. He always kept vigil with the dying, reading to them from the Holy Scriptures by firelight inside their hut, comforting, praying and baptising the unbaptised. He often used Philippians 3:21 which says, '... and he will transfigure these wretched bodies of ours into copies of his glorious body'. As he read the scriptures to the dying, the more able lepers always kept vigil with him.

By doing so, John changed Mutemwa from a place of those who are cut off to a place where lives were/are healed (Karombo 2019:para 10). Rance (2018) concurred that living in a tin hut that lacked water and sanitation, just outside the leprosy compound, John Bradburne transformed the leprosy centre into a community of peace, joy and love. In order to feed and nourish himself spiritually, he sometimes spent hours of meditation and prayer on the pinnacle of the nearby Chigona Mountain, which has since become the most popular and frequently visited place of all at Mutemwa leper colony (Mutape Interview, 29 September 2017). For pilgrims, it is a mountain 'that hold healing and transforming powers' (Karombo 2019:para 10). Having overcome the barriers of distance and time, he continued to live according to the Rule of the Order of Franciscans at Mutemwa Leprosy Centre. The Rule, amongst other things prescribed that he should 
sing the daily office of Our Lady (Mother Mary), rise at dawn for Martins and end the day with Vespers and Compline (Rance 2018). The demands and expectations of his Franciscan Rule, however, did not deter or disturb his desire and mission. In fact, it further re-directed his focus and dream, much to the appreciation of his community members.

\section{The death of Bradburne}

After a decade of dedicated service at Mutemwa leprosy centre, it is alleged that John met with his untimely violent death at the hands of the Rhodesian Freedom Fighters (possibly ZANLA guerrillas) who accused him of being a spy and an informer of the then Rhodesian government. He was given the chance to flee the country but he turned it down (Karombo 2019:para 10). McLaughlin (1996:288) also mentioned the name of Bradburne as one of the 25 expatriate missionaries killed during the war, from December 1976 to February 1980. Rogers (2017), in his untold story that needed to be told, a story of 30 Catholic missionaries who were brutally killed in Rhodesia (now Zimbabwe), between 1976 and 1988 does confirm that John was one of them.

It was alleged that, as a Second World War ex-combatant and also, Britain being Zimbabwe's colonial Master then, Bradburne had some links with the colonial system of his mother country. For that reason, he was suspected of double dealing. In addition, John had also not enjoyed a good name from some of the local people. During his tour of duty at the centre, for one reason or another, certain people from neighbouring villages had shown hostility to John. Thus, Dove (1990) writes:

\begin{abstract}
... the odds were against John - enemies amongst the locals, enemies amongst the mujibhas [male war collaborators], enmity with the white RLA. Even some whites in the security forces wondered how he had survived without helping the 'other' side. (p. 282)
\end{abstract}

Having been warned several times by his Jesuit friends and other colleagues from the neighbouring Mutemwa area of the impending danger, Bradburne, however, refused to leave his 'cave'. Describing John's last moments and his fateful last hour on the 5th of September 1979, Moore (2009) writes:

Thirty years ago this month [September], Robert Mugabe's guerrillas kidnapped the former warden of a leper colony in what was then Rhodesia. They took him into the bush and subjected him to mockery in front of a crowd, offering him girls to sleep with, trying to make him dance and to eat excrement. The next day their leader interrogated him. He said little but knelt and prayed ... Eventually they marched him out of the bush to the main road. Their leader told him to walk ahead and turn and face him. He did so and again knelt and prayed. When he rose, the guerrilla shot him. His half naked body was left by the road side. The ex-warden's name was John Bradburne.

At the First International Conference dedicated to John Bradburne's poems and documented by Tomei (2018), Marco Impagliazzo placed John in the context of Christian martyrdom, drawing attention to the way his death could be viewed as a significant moment in the 'ecumenism of blood' experienced in Africa during the 20th century, which he described as the most violent of all centuries.

After the violent death, John was buried at Chishawasha Mission cemetery in Harare Diocese. It is reported that a pool of blood was noticed beneath his coffin when people had not acted according to his initial request and wish of being buried in the Franciscan Habit. When he was finally buried with his much desired vestment, the blood miraculously stopped. This incident became one amongst a series of other miracles reported after John's burial that could have triggered Mutemwa pilgrimages. Without looking at John's dark side, amongst many other things, his lasting legacy is that Mutemwa is currently a place of pilgrimages, and there is a growing movement in support of his cause for sainthood, with numerous pilgrims claiming to have been healed by his intersession (Murape 2012). A memorial service that has since become a national Catholic event, in full support of all Catholic bishops is held at Mutemwa annually. The service draws more than 25000 pilgrims (Mandiedza, Interview, 29 September 2017). In September 2019, Catholic Bishops in Zimbabwe opened the process for John's beatification and canonisation (Karombo 2019:para 10). This came after the Zimbabwe Catholic Bishops signed a letter of placet on the cause of John's Beatification on the 30th of April 2019. Ground work on the Cause of John's Beatification had been going on for many years with the John Bradburne Memorial Society and the Archdiocese of Harare pushing for the Englishman's recognition amongst other Catholic saints (Kugwa 2019:para 1).

Thus, a comprehensive survey of the dynamics and dialectics of African Christianity, Zimbabwe in particular, reveals that of the many sacred places dotted around the Zimbabwean Christian landscape, Mutemwa shrine, is perhaps the most visited and popular, now attracting thousands of both Christians (particularly Catholics) and non-Christians from all the 10 provinces of Zimbabwe. Whilst the majority of the pilgrims are mostly women, countless men and children from all Zimbabwe's eight Catholic dioceses have also joined the bandwagon. These are: Harare and Bulawayo Archdioceses, Gweru, Chinhoi, Mutare, Hwange, Gokwe and Masvingo dioceses.

\section{The nature and character of Mutemwa pilgrimages}

Ever since the time of the violent demise of John Bradburne in 1979 and the subsequent blood miracle, numerous other miracles and extraordinary events were reported at Mutemwa Leprosy Centre, thereby instantly putting Mutemwa on the limelight as a place where prayers were/are answered. To that effect, driven by social, political, economic, cultural and religious challenges, pilgrims from all the eight dioceses in Zimbabwe flooded Mutemwa shrine at individual, family, parish or diocesan levels. Whilst some people came and continue to come for praise and thanksgiving, the majority of 
those who flock Mutemwa shrine come with requests not thanksgiving (Chagonda, Interview, 28 September 2017). They often visit the shrine when they are faced with problems in their lives or when they are undergoing unwelcome changes in their lives' direction or relationships. According to information gathered through interviews, common requests include: healing, prosperity, end to spells of misfortune, favours to see miracles, better paying jobs, requests for children (barrenness), success in examination, favours at workplaces and the forgiveness of sins, amongst many others (Mutape, Interview, 29 September 2017).

As observed and documented by one of the authors, when pilgrims come to Mutemwa shrine for prayers, particularly in the month of September for the death anniversary of John Bradburne, there is often a general pattern of prayer and spiritual exercises that are routinely followed. These include: queueing outside the tin hut where John Bradburne used to stay. Long winding queues are usually for some common and/or individual prayers. Whilst other pilgrims drop petitions into the box inside the tin house, others often hang their rosaries onto the carved image of John and/or on to the Blessed Virgin Mary's statue. Scores of other pilgrims would also pray near the cross that is planted on the mountain top as they await common spiritual exercises. Whilst scores of pilgrims queue for confessions, others would leave bottled water over night in the tin hut presumably for blessings from Bradburne, the martyr of charity. Narrating his experiences at Mutemwa shrine during one of his many visits, Murape (2012) underlined:

\footnotetext{
Around $10 \mathrm{pm}$, there was a vibrant Eucharistic celebration which lasted for about 2 hours. At the end of Mass, there began a long procession up Chigona mountain. Most of the pilgrims took part in this. With lighted candles, and while reciting the rosary and praying the way of the cross, punctuated with solemn songs, the great crowd of pilgrims slowly ascended the mountain, with the last group arriving at the summit in the early hours of the morning. At the crest of the mountain, a number of sermons were preached, especially by lay people. Prayers were recited and a lot of singing was done. Meanwhile, a number of people tried to get as close as possible to the cross planted there. Towards sunrise the pilgrims then began to descend from the mountain top. A good number of them were seen taking with them water, soil, stones, grass and herbage from the mountain. Having congregated at the John Bradburne site [again], the pilgrimage concluded with a Eucharistic celebration which began at around $6 \mathrm{am}$, after which the pilgrims began to journey back to their respective places [and dioceses]. (p. 8)
}

What has been observed by the authors, confirmed and also described by Murape is, perhaps the general pattern of the behaviour of pilgrims, whether they come for weekly, monthly or yearly visits. What is characteristic of the general pattern of behaviour is that it consists of both liturgical and non-liturgical spiritual exercises and devotions. Liturgical devotions such as Eucharistic celebrations, praying the rosary and Stations of the Cross, perhaps deserve particular mention.
Accepted traditional Christian, (particularly Catholic) theology, views the Eucharist as the source and summit of the Christian faith (Catechism of the Catholic Church 1994:336). As the greatest symbolism and most venerable sacrament, the Eucharist is the sacrament in which Christ the Lord himself is contained, offered and received and by which the church continually lives and grows. The Eucharistic sacrifice, the memorial of the death and resurrection of the Lord, in which the sacrifice of the cross is forever perpetuated, is the height and the source of all worship and Christian life. In fact, it is the highest form of prayer within the Catholic Church circles. Through it, the unity of God's people is signified and brought about, and the building up of the body of Christ is perfected. The other sacraments and all the apostolic works of Christ are bound up with and directed to it (Canon 897).

The Catholic Church stipulates that, whilst they express their faith in the real presence of Christ under the species of bread and wine in the liturgy of the Mass, they also get the opportunity to present their intentions and requests during the celebration of the same sacrifice. It is a common phenomenon that during the celebration of Mass at Mutemwa shrine, pilgrims are asked to put their requests and petitions in writing so that they are offered and presented to God, particularly during the time of consecration. Huge boxes or clay pots are provided for this ritual exercise. Thus, with the celebration of the Eucharist and sometimes adoration of the Blessed Sacrament (exposed), for many pilgrims, the Mutemwa pilgrimage becomes a life changing, metamorphic and transformational experience.

In addition to the transmuting experience brought about by the Eucharistic celebration and adoration, often associated with Mutemwa processions are the Stations of the Cross and recitation of the rosary, not to mention the spiritual powers that are often associated with holy water (Mutape, Interview, 29 September 2017). Stations of the Cross or Way of the Cross, also known as Way of Sorrow or Via Crucis, refers to a series of images depicting Jesus Christ on the day of his crucifixion and accompanying prayers. The Stations of the Cross that grew out of imitations of via Dolorosa in Jerusalem which is believed to be the actual path Jesus walked to Calvary are so significant in the lives of pilgrims as they often use them to request for fortunes from God through Christ, the suffering servant. Similarly, the church's devotion to the Blessed Virgin Mary is intrinsic to Christian worship (Lk 1:48). The church rightly honours Mary (the intermediator) with special devotion through the rosary and also directs their prayers to Christ through her. From the most ancient Christian times, Mary has been honoured with the title of 'Mother of God' to whose protection the faithful fly in all their dangers and needs (Catechism of the Catholic Church 1994:255). Thus, with the aid of both the Stations of the Cross and the rosary, Mutemwa pilgrims experience the joyous feelings of spiritual connection and being close to God, which then enables them to discern his will and guidance especially in times of transition and difficulties. Above all, with prayers directed to 
God and Christ through Mary, pilgrims become optimistic that they stand a chance to solicit for God's favours that would eventually transform their miserable lives for the better (Banda, Interview, 30 September 2017).

Whilst the liturgical devotions may all be in tandem and conformity with the teachings and traditions of the Catholic Church, it is the area of non-liturgical devotions and individual experiences of pilgrims that is, perhaps slowly becoming a cause for concern. The belief that anything that may be found at Mutemwa shrine or Chigona Mountain contains John Bradburne's magical healing powers is a matter that has since called for close scrutiny and may require both theological and pastoral re-alignment. The uncontrolled practices such as embracing or kissing of the cross, collection of stones, leaves, soil, grass and herbage from the shrine is indicative of the contention that Christians who visit Mutemwa shrine are slowly but dangerously drawing closer and closer to the domain of popular superstition. This behaviour has made critics to suggest and recommend that pilgrims should concentrate more on charity and social work in their respective areas rather than spending huge amounts of money on Mutemwa trips (Masango Farai, Interview, 10 August 2017). Elements and traits of the 'Pentecostal' beliefs and interpretations of individual experiences at Chigona Mountain also reveal that Mutemwa pilgrimages have taken a slant and tilt towards medieval popular superstition. In an interview conducted by Murape (2012) on the 4th and 5th of September 2011, the researcher also underlines:

When asked whether they had any religious experiences at Mutemwa, many acknowledged so ... Quite a few of the respondents said they once saw the sun changing colours. A few more said the sun changed into [blood] or a sacrament (the Eucharistic host). Still others claim to have seen the face of Jesus in the centre of the sun. A good number of the respondents said they experienced the black granite cross planted on top of the mountain glowing as if engulfed in light and/or rotating. Some claim they saw visions including that of the Blessed Virgin Mary and those of men dressed in bright clothing, akin to accounts of biblical visions of angels. There are two claims of religious experiences which seem worth mentioning here... The first witness says that once a priest laid his hands on him, he saw flashes of fire which looked like bolts of lightning. Another one recalls two visions she had experienced. The first one was of a silver monstrance suspended mid-air and under it was written, 'Look after my people'. The second one was a word in the form of a flame under John Bradburne's stature which read, 'Ignite'. (p. 10)

During interviews with the author soon after the anniversary of John Bradburne in 2017, one of the pilgrims also confirmed that she had witnessed a white cloud on top of the cross. 'I invite everyone to visit Mutemwa to see for themselves', she commended'.

\section{She shouted:}

My experience this year at Mutemwa was something absolutely unexpected, not only for the emotions that I experienced but also the ecumenical nature of the event. I also witnessed my private miracle.
Another pilgrim said:

I would like to thank the Catholic Bishops for putting the anniversary of John Bradburne on our liturgical calendar. I will definitely miss this electrifying atmosphere when I go back home.

As underlined by Karombo (Banda, interview, 30 September 2017), just recently, when the Zimbabwe Catholic Bishops, together with Catholics from all corners of Zimbabwe met at Mutemwa Shrine from the 5th to the 7th of September 2019 to celebrate the start of the canonisation cause for John Bradburne, one of the bishops also confirmed that he witnessed a miracle of a dancing sun.

To that end, whilst the majority of Mutemwa pilgrims visit the shrine in order to get time of quiet reflection and a chance to re-energise mentally, physically and spiritually refreshing their dropping spirits for purposes of spiritual direction, there is a veiled and concealed element that continues to push some pilgrims simply just to come and touch a holy relic, which is believed to carry some good fortunes or to witness a miracle. For that reason, pilgrimages become acts of devotion to God for an exchange for a miracle, not necessarily moments of inspiration by the saint or saints who would have gone before them. This development has led a number of critics of Mutemwa pilgrimages to ask the question, 'what have all the extraordinary experiences recorded at Mutemwa shrine to do with piety and unspoilt religion?' Before the article makes an analysis of characteristics of piety according to the mind of Jesus, it is vital to first scan through the scriptures in order to underline the religious significance and value of shrines. A scan through sacred scriptures may also assist in detecting and re-discovering therein the prophetic voice that remonstrated and reprimanded those who practised superstition and religious formalism.

\section{Old Testament shrines and pilgrimages}

A quick scan through the Old Testament reveals that the theme of prayer, places of prayer and pilgrimages is woven into many of the books which make up the Old Testament canon, particularly the Pentateuch. ${ }^{4}$ The Pentateuch articulates the main sacrifices, ordinances and sacrificial systems that God ordained and placed at the very centre and heart of the Jewish national rite to guide holocaust offerings, meal offerings, peace offerings, sin offerings and trespass offerings (Lv 1-7). From as far back as Abraham or even earlier, sacred places such as graves, mountains, rivers, sanctuaries and at a later stage, Temples, occupied an immense value.

As underlined in the New Bible Dictionary (Marshall, Wiseman \& Packer 1997), the concept of pilgrimage as a

4.The name 'Pentateuch' is given to the first five books of the Bible. It comes from Greek words meaning 'five scrolls'. It is, however critical to think of the Pentateuch Greek words meaning ' 'ive scrolls'. It is, however, critical to think of the Pentateuch as one book divided into five sections, rather than as five books rolled into one. In this way, justice is done not only to its Hebrew origin, where it was called the 'Torah' (LAW) or the 'Five Fifths of Moses', but also to its own inherent unity (The Lion handbook to the Bible 1994:122). 
journey of religious volition or obligation to a sacred spot such as Abraham's visit to Moriah (Gn 22:1-19), his worship of Yahweh at Bethel (Gn 12:8), Shechem (Gn 12:7) and Horeb (Gn 13:18) and many other revelations of God to the Patriarchs such as Jacob (Gn 28:11-19) is known from remote antiquity even though the Bible lacks a technical term for it. Any place held in veneration was, therefore, liable to attract pilgrims as the earliest Old Testament records show and reflect. Porter also confirms that in the popular Judaism of the time, there was apparently a great reverence for such great figures as Patriarchs and Prophets, their powers of intercession and also for their tombs. Such devotion can/could be seen as one source for the later Christian veneration of saints and the custom of pilgrimages to their burial sites (Porter 2001:72). Thus, there was visible evidence of an increasing veneration of the burial places of Israel's heroes around the time of Jesus, and miracles and healings were believed to be granted to pilgrims who visited them. The same also applied to numerous physical journeys to different shrines, which had deeper spiritual meaning in the Old Testament.

Apart from the veneration of tombs of Jewish religious heroes, even though shrines such as Shechem (Gn 12:6), Bethel (Gn 28:19), Beersheba (Gn 21:33), Gilgal (Js 10:6), Dan (1 Ki 12:31), Shiloh (1 Sam 1-3), Gibeon (1 Ki 3:4) and Hebron (Gn 13:18), amongst others were held in high esteem, when the Jerusalem Temple was built around 957 BC, journeys to the statutory feasts at the Jerusalem Temple enjoyed exclusive prestige on the Jewish sacrificial calendar. In the history of Israel:

[O]f all Jewish sojourns, the pilgrimage to Jerusalem appeared to have, during the time of David and Solomon, gained more importance than any other places of worship in the southern kingdom of Judah. (Murape 2012:13)

As the Ark of the Covenant made the Temple holy, in time, the entire city of Jerusalem thus developed into a centre of pilgrimage, a place where God could be encountered in a special way. Pilgrimages to Jerusalem on the three major feasts, namely Passover (unleavened bread), Pentecost and Tabernacles became a requirement for all male Israelites who were often joined by other family members. Even during periods of exile, pilgrimages to the much venerated Jerusalem Temple took on an additional emotional and spiritual significance (Dyas n.d. para 3). As indicated earlier, many more feasts and sacrifices such as holocausts, meal, peace, sin and trespass offerings were associated with certain designated places of worship and understandably so, these places acquired unparalleled significance as people frequented such places for social, cultural, religious or even political problems and solutions.

However, whilst places of prayer and pilgrimages were held as such in the Jewish sacrificial system, throughout the history of the Jewish people, religious formalism ${ }^{5}$ has been

5.Of all the southern and eastern African tribes, the southern Shona have the most elaborate cult for worshipping and consulting the Supreme Being. For centuries they have believed in Mwari as the final authority behind their ancestors, a High ancestors, but one who could be consulted on matters of communal import. Thus, ancestors, but one who could be consulted on matters of communal import. Thus,
fundamentally, pre-Christian belief in a Supreme Being contributed considerably fundamentally, pre-Christian belief in a Supreme Being contributed consider
towards shaping the destiny of the Shona people (Confer, Daneel 1970:15). visible and categorically castigated by several prophetic voices in their midst. Mc Callum (n.d. para 2), Lukefahr (2000) and the Lion Handbook to the Bible (Alexander \& Alexander 1994), amongst many other sources underline that even though religious formalism is a human problem found in all religions of the world, including Christianity and contemporary settings, it is roundly condemned in the Bible. Mc Callum, for example, observed that instead of focusing on the ethical principles of religion, pilgrims can focus on the outward forums such as sacred buildings or shrines in which worship occur, calendar of sacred days and times around which religious life is oriented or the rituals through which followers can experience the sacred. He also mentions that formalism ${ }^{6}$ can be in the form of special dress, diet, language or other behaviour unique to that religion.

As underlined in the Lion handbook to the Bible, when the people of Israel had become a nation, redeemed from Egypt and given the Law, the prophetic voice was always in their midst, constantly reminding them of their dependence on God's forgiveness and mercy (Alexander \& Alexander 1994:370). Regrettably, the people of Israel were constantly falling down on their calling and promises and the prophetic voice again and again recalled them to the whole point of their existence as their fault was sometimes more of a reversal of right priorities. Whilst sacrifices and pilgrimages were intended to make provisions for lapses into disobedience, there were periods in the Old Testament history when they were seen as substitutes for the life of obedience, love and mercy. They were simply viewed as ritual techniques for keeping God happy.

By doing so the entire sacrificial system had been corrupted into a sort of non-moral ritualism and several prophets who tried to address that issue such as Amos, Hosea and Isaiah, amongst others at first sight seemed to deny or doubt the divine authority behind the 'empty' sacrifices. Thus, the prophet Hosea lamented, 'What I want is love, not sacrifice [or pilgrimages], knowledge of God not holocausts' (Hs 6:6). To that same effect, Abraham and Sarah were blessed with a child not because they had visited a shrine or burnt some incense but simply because they had faith in God and had showed hospitality to the visiting angels who disguised as ordinary men (Gn 18:1-15). Similarly, Rahab (Js 2:1-21) the prostitute was also blessed not necessarily because she had offered several burnt offerings to God but because she had done an act of mercy. Hiding the two spies was considered a critical ethical act of religion worth emulating. The list of individuals who were blessed independently of performances of rituals and pilgrimages is endless. Whilst evidence of religious formalism is so visible in the Old Testament, ironically, the New Testament also picked a significant portion of the Old Testament motifs, particularly with regard to exaggerated spirituality and popular superstition.

6.Mc Callum underlines that formalism refers to a tendency in religious thought and practice to shift focus from the abstract, the spiritual, the personal or the ethical practice to shift focus from the abstract, the spiritual, the personal or the ethical
principles in religion and focus towards the outward forms that embody that religion. 


\section{Prayer and places of prayer in the New Testament and Church history}

A brief survey and scan of the New Testament canon exhibits irrefutable evidence of devotions and pilgrimages that seems to have scriptural evidence and basis. The Gospel of John underlines that sometime after the cure of the nobleman's son, there was a Jewish festival, and Jesus went up to Jerusalem (Jn 5:1). As the Jewish Feast of Tabernacles drew near, Jesus' brothers wanted him to leave the place and go to Judea (Jn 7:4). Every year, in fulfilment of the Law, his parents used to go to Jerusalem for the Feast of the Passover (Lk 2:41). Now on the first day of the unleavened bread, his disciples asked him, 'where do you want us to make the preparations for you to eat the Passover?' (Mt 26:17). Then Peter stood up and began to address those who had come for the Feast of Tabernacles (Ac 2:14).

Whilst the New Testament could have picked the same pattern and design from the Old Testament, with the redemptive act of Jesus, the New Testament began to show some remarkable changes in thrust and emphasis. The disobedience and subsequent fall of humanity from grace as a result of disobedience (Gn 3:1-24) provided the background to the drama of redemption emphasised in the New Testament. In the Gospels, Jesus is presented as winning forgiveness for humankind through his death on the cross, thereby making it possible for individuals to return to God and eventually reach heaven (Dyas n.d. para 3). To that extent, the emphasis then shifted significantly from seeking and finding God in the earthily city of Jerusalem, this or that mountain (Jn 4:20), or any other place of prayer or shrine, to finding him in Jesus Christ who is believed to be the personification of God. To see him is to see the Father (Jn 14:7).

Even though Jesus ended his earthly life with a clarion call to imitate him by first and foremost radiating all the Christological qualities, the introduction or revival of veneration of saints and pilgrimages in the earliest days of the Church ushered in yet another phase in the history of Christianity. The belief in Christian martyrs and the sacredness of their burial places was critical in ushering this new trajectory. Algermissen underscored that the veneration of the saints and their relics, often practised at pilgrimages and also at other times in the Catholic Church was a very ancient Christian custom, found as early as the second century (Algermissen 1945:505). The cult of saints, centred on relics and pilgrimages to places made holy by them also continued through the Middle Ages up to the contemporary period. This was also inseparably linked to visits and journeys to the Holy Land to see the sites of Christ's life, passion, death and resurrection (Murape 2012:16).

As observed by Algermissen (1945:506), honour is paid to the saints because of the outstanding privileges of grace conferred upon them by God. Veneration given to saints is called cultus duliae [veneration] or cultus hyperduliae. Cultus hyperduliae designates the specially lofty honour reserved to Saint Mary, the Mother of God (theotokos). It is different from cultus latriae, which may be paid only to God. Amongst many other confirmations from several theologians, the Council of Trent (1545-1563) also declared that it was good and beneficial to invoke the saints and to venerate their images. Thus for Christians, particularly Catholics, saints intercede for them before God. Thus, the invocation of saints, as underlined by the Catechism of the Catholic Church, is indicative of the communion of saints (Catechism of the Catholic Church 1994:249), 'an expression of faith in the living communion of all members of the mystical Body of Christ in its most comprehensive sense' (Algermissen 1945:506).

Thus, related to cultus duliae, are pilgrimages and processions to such holy places in which countless believers give public praise to God, thank him for his benefits and plead for his blessings. Throughout the entire world, shrines for such religious devotions are visible. These include, amongst numerous others: Notre Dame d' Afrique (Algeria), Mary Queen of the Apostles (Cameroon), Shrine of Our Lady of Sorrows (Rwanda), Namugongo shrine (Uganda), Ngome Marian Shrine (South Africa), Basilica of Our Lady of Ransom (India), Our Lady of Help (Netherlands), Shrine of Our Lady of Fatima (Portugal) and Shrine of Our Lady of Mount Carmel (Spain). These and many others continue to be centres for spiritual energies, devotional prayers and pilgrimages.

With such means for obtaining grace and blessings, ironically, Christian history and thought has documented that as early as the earliest Christian centuries, the enemy planted darnel amongst the good crop. The darnel has since been identified as popular superstition that undermined piety amongst Christians. Brockman and Pescantini (1991:101) also confirmed that throughout Christian history, popular superstition undermined piety amongst many for centuries. The reverence because of relics at some point degenerated into a market where dishonest men and perhaps women produced fake relics to sell to the credulous faithful for the love of money. Some lay faithful went as far as stealing, inventing, altering and even multiplying relics of saints in order to get profit (Murape 2012:16). Franzen, Brockman and Pescantini concurred that during the Middle Ages, people believed in exaggerated visions and false miracles. Providing evidence to such exaggerated spirituality and superstition in the history of Christianity, Brockman and Pescantini (1991) wrote:

The abbey of Conques, in France, for example, wanted a magic statue in order to attract pilgrims, and so it [he] arranged to have a monk join another monastery in order to kidnap one. Miracle stories were made up to enhance the statue's value. Unfortunately, religious education of the people was haphazard ... (pp. 254-255)

Whilst popular superstition may not have directly triggered the Reformation, it was, however, mentioned by Franzen, Brockman and Pescantini as one of the key causes of the Reformation, alongside factors such as corruption in the 
church, disunity within the church, lamentable condition of the clergy and finally the immediate cause of the Reformationthe abuse of fundraising-indulgences (Brockman \& Pescantini 1991:101-103). The demon of popular superstition did not, however, die or disappear with the Reformation, counterreformation or the contemporary desire for ecumenism. In fact it has withstood the test of times, as it grew with time in many forms and different degrees of intensity and yet inseparably and intrinsically bonded to prayer, devotions and pilgrimages. In spite of its resistance (demon of superstition), the teachings of the Catholic Church have not been found wanting in providing the prophetic voice and further clarifications on the teaching of the Church with regard to pilgrimages.

\section{Catholic teaching on shrines, devotions and pilgrimages}

Within the Catholic Church circles, common devotions include: the Rosary, Stations of the Cross, the Sacred Heart of Jesus, the Holy Face of Jesus, Novenas to various Saints, pilgrimages and devotions to the Blessed Sacrament and the veneration of saintly images, amongst many other devotions. As already underlined, throughout the world, shrines have been established and pilgrimages in honour of such devotions are being emotionally held. The Roman Catholic Church, through her two governing codes, the Canon Law (1918) and Catechism of the Catholic Church (1994), ecumenical councils (particularly Vatican II) and many other post-Vatican pronouncements, has provided the much needed light on popular devotions.

Amongst many other things, the Second Vatican Council (1962-1965) forms the basis and springboard for the current Catholic liturgy as it aimed at restoring Catholic liturgy to its proper place (Murape 2012:18). According to Sacrosanctum Concilium, popular devotions of the Christian people (provided they conform to the laws and norms of the Church) are to be highly recommended, especially where they are ordered by the Holy See. Devotions proper to individual churches are also viewed as having a special dignity if they are undertaken by order of the bishops according to customs or books lawfully approved. The document, however, warns that such devotions should be so drawn up that they harmonise with liturgical seasons, accord with the sacred liturgy and also in some way to make sure that they are derived from liturgy and lead the people to it, as the liturgy is by far superior to any of them. Pope Pius XII in Mediator $D e i^{7}$ had also earlier recommended both private and public devotions.

Augmenting and perhaps reinforcing the Catholic position on shrines, devotions and pilgrimages, the current Roman Pontiff, Pope Francis views popular devotions as a genuine form of spreading the faith. He promotes and values popular

7 Mediator Dei is the Encyclical of Pope Pius Xil on Sacred Liturgy.................... the first papal document devoted entirely to liturgy. It suggested new directions and active liturgical participation of the faithful at all levels, including parish. The active liturgical participation of the faithful at all levels, including parish. The
Encyclical was promulgated in November 1947, about 16 years before Sacrosanctum Encyclical was
Concilium. religiosity, which every year sees millions of pilgrims flocking to shrines to entrust themselves and their loved ones to the Virgin Mary and the saints. As recorded and underlined by Martin (2016), Pope Francis argued:

In the shrines, in fact, our people live a deep spirituality, that of the piety that through centuries has reflected the faith with simple but very meaningful devotions ... It is a touchstone for both theology and pastoral activity. (Martin 2016:para 3)

Thus, ecclesiastical authorities throughout Christian history have always guided the faithful and shaped their liturgy by explaining and clarifying the concept of popular devotions. However, having surveyed both the African traditional religion, the Old Testament, the New Testament and the tradition of the Church, a discussion about the nature of piety may not be conclusive without outlining the key characteristics of piety according to the mind and expectations of Jesus.

\section{Characteristics of authentic piety}

The article has underlined in no uncertain terms that religious formalism cuts across all religions and cultures. Just as religious formalism was castigated and condemned in Judaism, so was it also admonished and attacked in the New Testament and the history of the Christian Church. Similarly, so should it also be criticised and denounced in the event that its elements re-surface and re-emerge in contemporary popular devotions. When the Jewish sacrificial system degenerated into ritual techniques for keeping God happy or substitutes for the life of obedience, love and compassion, prophets did not hesitate to raise their protest. When Jesus also spotted elements of religious formalism during his heydays, he recalled his followers and would-be followers to the whole point of their existence.

Amongst many characteristics of piety, authentic ones consist not in outward forms of religion. They do not at all consist in sacred buildings or shrines in which worship occurs or the calendar of sacred days and times around which religious life is oriented. They do not consist in rituals through which believers can experience the sacred or turning one's face towards East or West when praying. They do not consist in visiting Mecca in one's life time. Acceptable piety does not consist in special religious attire, diet, language or other behaviour unique to a particular religion or procession. It does not consists in praying with or without shoes, picking stones, relics, grass, soil or herbage from Mutemwa (or any other shrine in the world) or leaving bottles of water in Bradburne's tin hut overnight. Neither does it consist in spending sleepless nights on top of a religious mountain, experiencing miracles or seeing visions, praying the rosary or Stations of the Cross, embracing or kissing any cross or statue.

From a Christian point of view, piety is Christocentric. It underlines and underscores an imitation of Christ whereby believers radiate and reflect all the Christological qualities, beginning with leading a sinless life. Scriptures emphasise 
that point quite clearly: 'He committed no sin nor was any deceit found in his mouth' (1 Pt 2:22). 'He was tempted in all things as we are, yet without $\sin ^{\prime}$ (Hb 4:15). 'You know that he appeared in order to take away sins, and in him there is no $\sin ^{\prime}$ (1 Jn 3:5). Thus, as devotees move towards the centre and essence in identifying and realising their whole point of existence, doing away with sin may not be an option, for one's lifestyle often reflects and gives evidence of the life of the one living in his or her heart.

Being Christocentric is being 'other centred', 'other centric' or better still, 'fellowman centric'. Just as Jesus gave up his life for his friends, so did John Bradburne also spent the last 10 years of his earthly life at Mutemwa leper colony (1969-1979) as if to confirm and fulfil the scriptures which say, 'A man can have no greater love than to lay down his life for his friends' (Jn 15:13). The epistle of James also makes a similar emphasis when he writes, 'Pure, unspoilt religion, in the eyes of God is to come to the aid of orphans and widows when they need, and keeping oneself uncontaminated by the world' (Jn 1:27). The same recommendation was also made by Jesus when he said, 'For I was hungry and you gave me food, I was thirsty and you gave me drink, I was a stranger and you made me welcome; naked and you clothed me, sick and you visited me; in prison and you came to visit me' (Mt 25:35-37). The Good Samaritan's act of compassion towards a stranger also stands as a shining example for all generations, particularly in the area of piety. Thus, to the man who had asked him, Jesus recommended: 'Go and do the same yourself' (Lk 10:37). Following the same logic and thrust, if one is preoccupied with religious creeds or religious deeds, processions and pilgrimages, and has no time to be a 'Good Samaritan' in his own village or area, parish or diocese, then 'one is denying the teachings of Christ and breaking the Greatest Commandment'. In fact, one would be finding consolation in false religion that manifests itself only in outward forms (Roberts 1976:26).

In its classical settings, piety demands that pilgrims shift significantly from popular devotions just for the sake of devotions, shift from finding God on this or that shrine, grave or mountain to finding him in their fellowmen or fellow human beings. Anyone who says I love God and hates his or her brother is a liar (1 Jn 4:20). As pilgrims on earth, the tendency is to major the minor, over emphasise or perhaps exaggerate the practice of popular religion and let the true teachings of Jesus be clouded in the mists of shrines, devotions or pilgrimages.

Thus, the central ethical and moral fundamentals that underpin Christianity are critical and vitally important. Possessing piety implies Christ consciousness, especially his qualities of love and forgiveness, obedience, humility, peace loving, detachment, fasting and prayer (amongst many others) over and above intellectual, aesthetic and social values. Like a city built on the hill top or light put on a lamp stand, the presence and impact of pilgrims would, therefore, be inevitable. As their lives shine like light in the sight of men, seeing their Christ-like lives, the outside world would then give credit to God and be motivated, not necessarily to become Christians but to live according to the universal and timeless Law of Love, which itself is the essence, substance and backbone of Christianity.

\section{Conclusion}

Even though scholarly debate on true and false piety can split hairs because issues of truth or falsity cannot be verified, Mutemwa pilgrimages in Zimbabwe may require some regulations. Whilst the Second Vatican Council provided the impetus and springboard upon which contemporary liturgy hinges and is propelled ever forward, elements, traits, residues and relics of seemingly false religion and piety, religious formalism and exaggerated spirituality continue to be visible in the practice of contemporary popular religiosity. Whilst such elements continue to be perfected and ripened by some religious 'fanatics' to date, the fact that the origin and roots of such are possibly in the Shona traditional worldview, the Old and New Testaments is fundamental. In spite of the prophetic voice in the Old Testament and Jesus' repudiation and castigation of such in the New Testament, popular superstition continue to dictate the pace and direction in which liturgy at Mutemwa shrine often takes place. A sustained collective intervention by the Catholic Bishops of Zimbabwe in defining and further defining the link between popular religiosity, official Catholic liturgy and piety, may, therefore, be basic and critical. Known to the authors, no regulatory pastoral letter that provides the checks and balances on Mutemwa pilgrimages has since been issued by the Zimbabwe Catholic Bishops' Conference. Failure to do so may thus result in fatal and costly pastoral and theological errors that in the remote future is likely to witness a repeat of the Middle Ages and an eclipse of 'true piety' by popular superstition.

Whilst showers of praises have been heaped on Bradburne, Rogers (2017), however, avoids the hagiographical tone of several scholars and underline the other side of John Bradburne. Of all the negative aspects of his career amongst his cut off community of leprosy patients, at one point, John fell out with the Leprosy Association and was expelled from the colony. Over and above, as highlighted by Karombo (2019:para 10), the Mutemwa pilgrimage area itself has also been tainted by both homicides and suicides with at least three deaths in 4 years. A Catholic nun by the name Sr Plexedes Kamundiya, who was murdered in 2017 whilst praying in solitude at the Mutemwa Mountain, was the latest victim of such unfortunate incidents. For that reason, a handful of critics have regarded Mutemwa area not just as a place suspected of exaggerated spiritual exercises but also an 'unsafe' destination for solitary pilgrims.

\section{Acknowledgements Competing interests}

The authors declare that they have no financial or personal relationships that may have inappropriately influenced them in writing this research article. 


\section{Author's contributions}

S.M., M.M. and T.S. contributed to the design and implementation of the research, to the analysis of the results and to the writing of the manuscript.

\section{Ethical consideration}

This article followed all ethical standards for research without direct contact with human or animal subjects.

\section{Funding information}

This research received no specific grant from any funding agency in the public, commercial or not-for-profit sectors.

\section{Data availability statement}

Data sharing is not applicable to this article as no new data were created or analysed in this study.

\section{Disclaimer}

The views and opinions expressed in this article are those of the authors and do not necessarily reflect the official policy or position of any affiliated agency of the authors.

\section{References}

Alexander, D. \& Alexander, P., 1994, The lion handbook to the bible, Lion Publishing Company, Oxford.

Algermissen, K., 1945, Christian denominations, Herder Book Company, London. Bourdillon, M.F.C., 1976, The Shona peoples, Mambo Press, Gweru.

Brockman, N. \& Pescantini, U., 1991, A history of the Catholic Church, St Paul Publications, Nairobi.

Canon Law Society Trust, 1918, The code of Canon law, Ignatius Press, San Francisco, CA.

Catholic Church, 1994, Catechism of the Catholic Church, Pauline Publications, Nairobi.

Chimhanda, F., 2014, 'The liberation potential of the Shona culture and the gospel: A postfeminist perspective', Studia Historiae Ecclesiasticae 40 Supplement, 305-328.
Daneel, M.L., 1970, The God of the Matopo Hills: An essay on the Mwari cult in Rhodesia, Mouton, The Hague.

Dove, J., 1990, Strange Vagabond of God: The story of John Bradburne, Poolberg Press Ltd., Dublin.

Dyas, D., n.d., Pilgrims and Pilgrimage. Pilgrimage in the Bible, University of York viewed 07 July 2018, from https://www.york.ac.uk/projects/pilgrimage/content/ bible.html.

Gelfand, M., 1976, The Genuine Shona, Mambo Press, Gweru.

Karombo, T., 2019, 'Zimbabwean catholics celebrate canonisation cause for John Bradburne', viewed 20 November 2019, from https://www.ncronline.org/news/ people/zimbabwean-catholics-celebrate-canonization-cause-john-bradburne.

Kugwa, A., 2019, 'Zimbabwe Catholic bishops approve the beatification of John Bradburne', viewed 20 November 2019, from Catholicchurchnews-zimbabwecatholic-bishops-approve-the-beatification-of-john-bradburne.

Largerwerf, L., 1987, Witchcraft, sorcery \& spirit possession: Pastoral responses in Africa, Mambo Press, Gweru.

Lukefahr, O., 2000, A Catholic guide to the Bible, Verbum Bible, Kinshasa.

Marshall, L.H., Wiseman, D.J. \& Packer, J.L., 1997, The New Bible Dictionary, Intervarsity Press, Leicester.

Martin, I.S., 2016, 'Pope Francis says pilgrimages help spread the faith', viewed 10 July 2018, from https://cruxnow.com/church/2016/01/21/Pope-Francis-sayspilgrimages-help-spread-the-faith.

Mbiti, J.S., 1975,. Introduction to African religion, Heinemann, London.

Mc Callum, D., n.d., 'Formalism: What is it and why not?', viewed 10 July 2018, from https:www.xenos.org/essays/formalism.

McLaughlin, J., 1996, On the frontline: Catholic missions in Zimbabwe's liberation war, Baobab Books, Harare.

Moore, C., 2009, John Bradburne, viewed 20 July 2018, from https://www.telegraph. co.uk/JohnBradburne-who-turned-love-into-the-divine.html.

Murape, O., 2012, 'Mutemwa Pilgrimages: A case of popular religiosity', Unpublished Bachelor of Arts in Theology, Holy Trinity College, Harare.

Porter, J.R., 2001, The lost Bible: Forgotten scriptures revealed, Duncan Baird, London.

Rance, D., 2018, 'John Bradburne: The Vagabond of God', viewed 20 November 2019 from https://www.churchtimes.co.uk/articles/2018/29-march/books-arts/book review/john-bradburne-the-vagabond-of-God-by-didier-rance.

Ranger, T., 1999, Voices from the rock, Indiana University Press, Bloomington, IN.

Roberts, H.M., 1976, If you only knew: Reflections based on scripture, Mambo Press, Gweru.

Rogers, T., 2017, Missionary Martyrs of Rhodesia and Zimbabwe (1976-1988), Cluster Publications, Pietermaritzburg.

Shoko, T., 2006, 'Super Roma: Towards a new theology of healing in the Roman Catholic Church in Zimbabwe', Swedish Missiological Themes 94(3), 349-370.

Shoko, T., 2007, Karanga Indigenous religion in Zimbabwe: Health \& well-being, Ashgate, Aldershot.

Tomei, R. (ed.), 2018, John Bradburne: Mystic, poet and martyr, Scholars Publisheres, Cambridge.

Van der Merwe, W.J., 1957, The Shona idea of God, Morgenster Mission, Fort Victoria.

Zimbabwe Catholic Bishops Conference, 1989, Healing and salvation in the church, Pastoral Study Guide, Harare. 